\title{
Diversity and Abundance of Zooplankton at Palian Estuary, Trang Province, Southern Thailand
}

\author{
Tueanta Ramarn ${ }^{1}$, Hattaya Pet-Arwut ${ }^{2}$, and Sirilak Chuaypanang ${ }^{3}$ \\ ${ }^{1}$ Department of Biology, Faculty of Science, Thaksin University, Thailand \\ ${ }^{2}$ Department of Biological and Environmental Science, Faculty of Science, Thaksin University, Thailand
}

\begin{abstract}
Diversity and abundance of zooplankton were studied at Palian Esutary, Trang province, South of Thailand. Zooplanktons were collected using plankton net from November 2008 - January 2009 during Wet period. 18 genera from 6 phylum were observed from this present study, namely kingdom Annelida, Mollusca, Chaegtognatha, Echinodermata and Chordata. Most of them are merozooplankton (67\% of zooplankton population). Species composition were not differed between sampling station which copepods was the dominant group, especially calanoid and cyclopoid copepods. Brancyuran, crustacean naulii and mysis larvae were the secondary dominant groups. Based on these finding, it could be concluded that the relative high zooplankton species diversity in the Palian estuary, Trang province, is an indication of the healthy state of the estuary.
\end{abstract}

Keywords: Diversity, Abundance, Zooplankton, and Trang Province

\section{Introduction}

Zooplankton is planktonic invertebrate and larval stages of some marine fish that rely on water currents to move any great distance. Zooplankton is abroad categorization spanning a range of organism sizes that includes both small protozoans and large metazoan. Zooplankton includes holoplanktonic organisms whose complete life cycle lies within the plankton, and meroplanktonic organisms that spent part of their life cycle in the plankton before metamorphosis to either neckton or sessile, benthic existence (Guy, 1992). They represent an important trophic niche in aquatic ecosystem, as they constitute the most important link in energy transfer between phytoplankton and higher aquatic fauna (Hickman et al., 2001). Zooplanktons are importance component to coastal ecosystem, linking the primary producers (by consuming phytoplankton, mainly various bacterioplankton and sometime zooplankton) and higher trophic levels (Ferdous and Muktadir, 2009).

\section{Material and Method}

\subsection{Sample collection}

The sample locations for zooplankton were located at the Palian estuary, Trang province, southern Thailand (Fig. 1). Zooplanktons were sampled on the daytime monthly from November 2013 - January 2014 during low tide using standard plankton net with mesh size $125 \mu$. All samples were fixed in $4 \%$ seawater-formalin solution [Grabe et al., 2004].

In addition, water parameters; salinity, temperature, $\mathrm{pH}$, and $\mathrm{DO}$, were recorded shortly before samples collection using YSI.

\subsection{Laboratory Analysis}

In the laboratory, zooplankton were identified and counted using stereomicroscope and compound microscope. The zooplanktons were identified. All identifications were based on the outer morphological characteristics.

\subsection{Data Analysis}

Analysis of Variance (ANOVA) was conducted to compare difference in zooplanktons abundance between stations. All data set were first tested for normality and homogeneity as a required for parametric analysis (Sokal and Rolf, 1998). All statistic analysis was performed using the SPSS version 11.5 software package. 


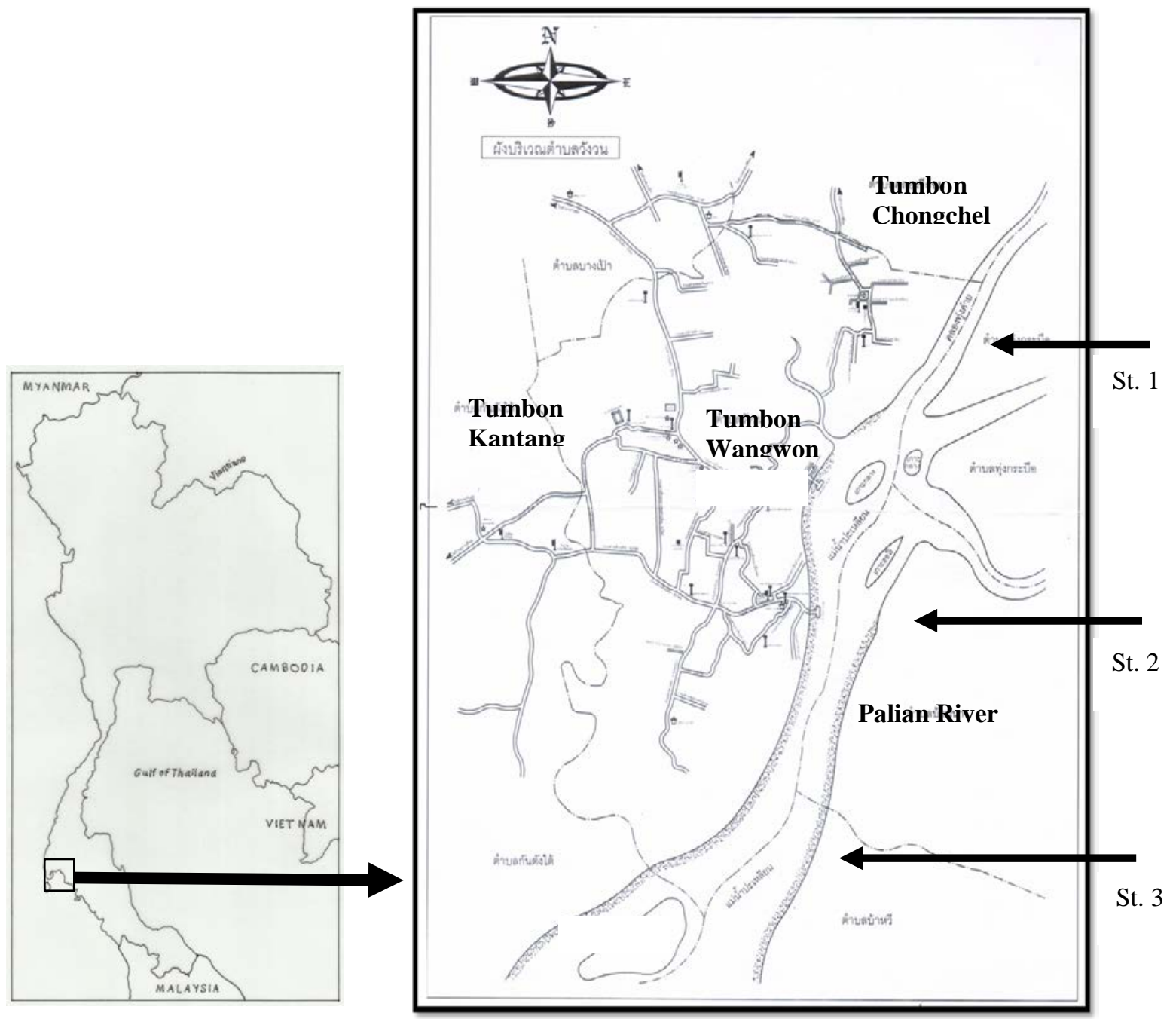

Fig. 1: Map showing the sampling stations at Palian Estuary, Trank Procinve, southern Thailand

\section{Results}

\subsection{Water parameters}

Water parameters were recorded as in the normal ranges (Table I). Salinity was constantly through the study period, ranged $15.83 \pm 0.30-18.02 \pm 1.68 \mathrm{ppt}$. Temperature varied from $27.51 \pm 0.16-30.82 \pm 0.05{ }^{\circ} \mathrm{C}$ during November to January 2014. $\mathrm{pH}$ values were also stable for both sampling stations, ranged of 7.34 \pm 0.09 $8.80 \pm 0.08$.

TABLE I: Water parameter during sampling period at Palian estuary, Trang Province, Southern Thailand

$\begin{array}{cccc}\text { WATER PARAMETER } & \text { NOVEMBER } & \text { DECEMBER } & \text { JANUARY } \\ \text { DEPTH (M) } & 3.40 \pm 0.37 & 3.22 \pm 0.28 & 2.45 \pm 0.23 \\ \text { TRANSPARENCY (M) } & 0.19 \pm 0.04 & 0.24 \pm 0.04 & 2.45 \pm 0.23 \\ \text { TEMPERATURE }\left({ }^{\circ} \mathrm{C}\right) & 30.82 \pm 0.05 & 29.97 \pm 0.42 & 27.51 \pm 0.16 \\ \text { DO (MG/L) } & 6.34 \pm 0.24 & 6.41 \pm 0.27 & 7.52 \pm 0.36 \\ \text { SALINITY (PPT) } & 15.83 \pm 0.30 & 19.97 \pm 0.22 & 18.02 \pm 1.68 \\ \text { PH } & 7.34 \pm 0.09 & 8.80 \pm 0.08 & 7.53 \pm 0.04\end{array}$

\subsection{Zooplankton diversity and abundance}

18 taxa in 6 Phylum of zooplankton were found. There are Phylum Annelida, Arthropoda, Mollusca, Chaetognatha, Echinoderamata and Chrodata (Table 1). Among them, phylum Arthropoda was the dominant 
group, consist of $90 \%$ of zooplankton population, followed by phylum Mollusca (4\%), Phylum Chaetognatha, Phylum Chrodata (2\% for each phylum) Phylum Annelida and Phylum Echinodermata (1\%) (Fig. 2). Most of zooplanktons are merozooplantkon (67\%), except cyclopoid copepod, calanoid copepod, harpecticoid copepod, isopod, Sagitta sp. and Oikopleura sp (Table II).

TABLE II: Zooplankton in Palian Estuary, Trang Province, Southern Thailand

\begin{tabular}{|c|c|c|}
\hline Taxa & Holoplankton & Meroplankton \\
\hline \multicolumn{3}{|l|}{ Annelida } \\
\hline Larva of sabellariid & & / \\
\hline Larva of spoinid & & / \\
\hline \multicolumn{3}{|l|}{ Mollusca } \\
\hline Bivalve larvae & & / \\
\hline Gastropod larvae & & I \\
\hline \multicolumn{3}{|l|}{ Arthropoda } \\
\hline Calanoid copepod & I & \\
\hline Cyclopoid copepod & / & \\
\hline Harpecticoid & I & \\
\hline Cirripde nauplius & & / \\
\hline Cypris larvae & & / \\
\hline Isopod & / & \\
\hline \multicolumn{3}{|l|}{ Shrimp larvae } \\
\hline Protozoea & & I \\
\hline Mysis & & I \\
\hline Branchyuran larvae & & I \\
\hline Crustacea larvae & & I \\
\hline \multicolumn{3}{|l|}{ Chaetognatha } \\
\hline Sagitta sp. & I & \\
\hline \multicolumn{3}{|l|}{ Echinodermata } \\
\hline Ophiopleuteus larvae & & / \\
\hline Brittle star lavae & & I \\
\hline \multicolumn{3}{|l|}{ Chordata } \\
\hline Oikopleura sp. & / & \\
\hline
\end{tabular}

Zooplankton densities varied from 2,076.17-2600.00 individuals $\mathrm{m}^{-3}$. Copepods were the dominant group, especially Calanoid (1,025.55-1,5421.06 individuals ${ }^{\mathrm{m}-3}$ ) and Cyclopoid copepod (9,419.66-14,187.66 individuals $\mathrm{m}^{-3}$ ). However, branchyuran larva, crustacea nauplius and mysis larvae were collected in low number but there were present in all sampling collections. There densities vary from $612.33-9,200,1,252.21$ 6,204.10 and 2,323.36-3,344.40 individuals $\mathrm{m}^{-3}$, respectively.

Spatial variation in zooplankton abundance was observed from present study. The significant difference (ANOVA, $p<0.05$ ) was observed in zooplankton abundance among sampling stations. The highest number of zooplankton was observed at Station 1 (mean density $=2,717.4 \pm 386.3$ individuals $\mathrm{m}^{-3}$ ), followed by Station 2 $\left(2,107.8 \pm 252.7\right.$ individuals $\left.\mathrm{m}^{-3}\right)$ and Station $3\left(1,525.2 \pm 263.0\right.$ individuals $\left.\mathrm{m}^{-3}\right)$.

No temporal variation in zooplankton abundance (ANOVA, $p>0.05$ ) was observed between study period. However, the maximum zooplankton number was recorded in November 2013 with mean density was 2,438.5 \pm 639.9 individuals $\mathrm{m}^{-3}$. Zooplankton abundance decreased after that, 2,174.7 \pm 533.4 individuals $\mathrm{m}^{-3}$ and 1,737.2 \pm 492.3 individuals $\mathrm{m}^{-3}$ in November 2013 and January 2014, respectively (Fig. 3). 


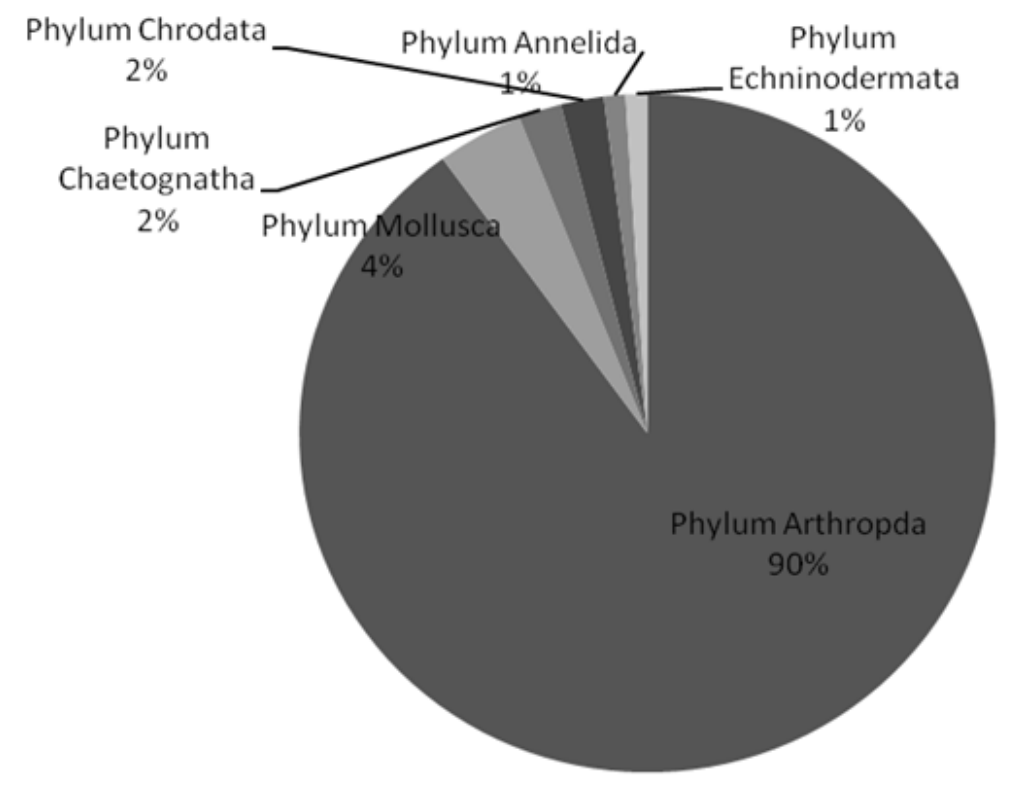

Fig 2. Percent composition of zooplankton collected from Palian Estuary, Trang Porvince, Southern Thailand during study period.

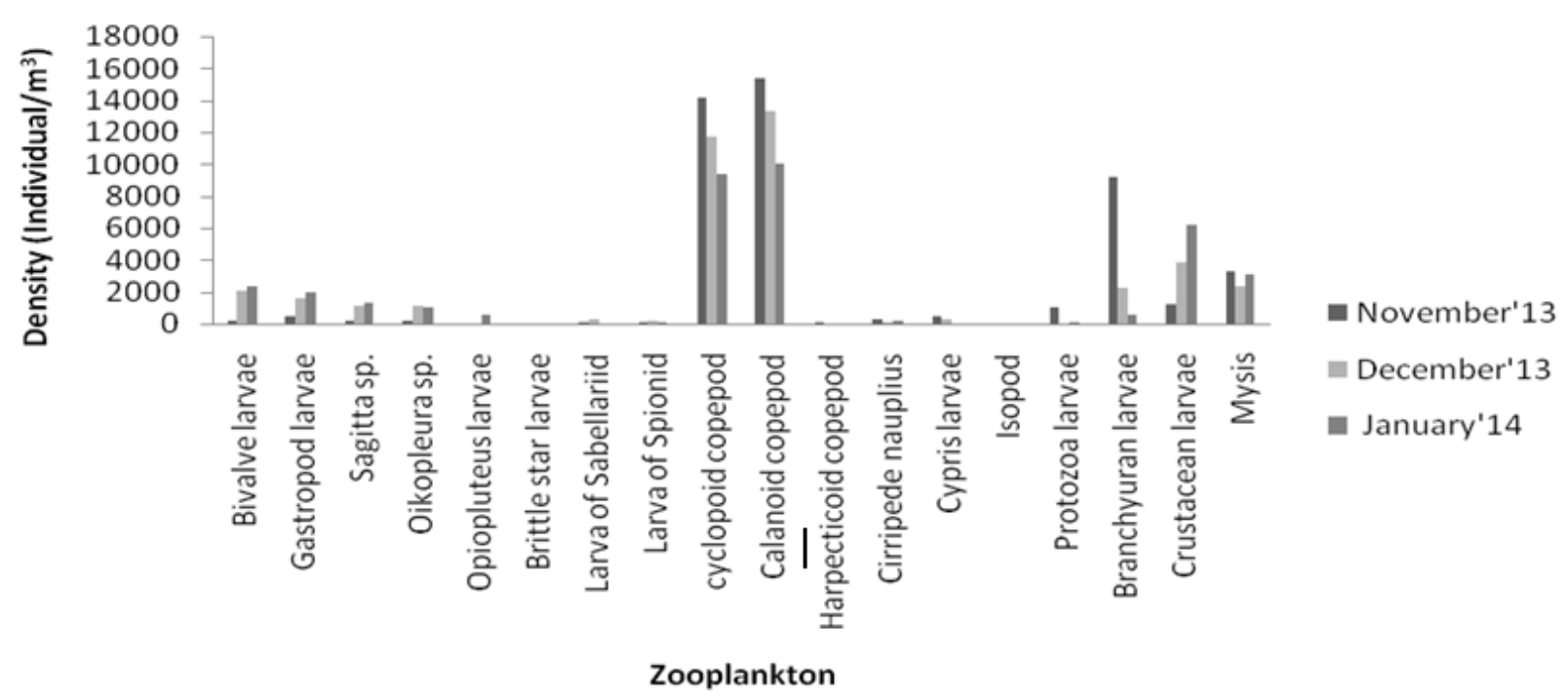

Fig 3: Temporal variation in zooplankton abundance at Palian Estuary, Trang Province, Southern Thailand during November 2013-January 2014.

\subsection{Diversity index}

Shannon -Weiner diversity index is highest on November $(0.94 \pm 0.05)$, followed by December $(0.82 \pm 0.10)$ and January $(0.73 \pm 0.05)$, however, not significant difference $(p>0.05)$. While richness index and Evenness index were highest on December, followed by November and January, however, not significant difference $(p>0.05)$. Richness index varied from 1.35 $\pm 0.08-1.73 \pm 0.08$. Evenness index ranged from $0.41 \pm 0.03-0.54 \pm 0.38$ ) (Table III). 
TABLE III: Diversity index of zooplankton from Palian Estuary, Trang province, Southern Thailsnd during November 2013-January 2014

\begin{tabular}{llll}
\hline Month & H' index & Richness & Evenness \\
\hline & & & \\
November & $0.94 \pm 0.05^{\mathrm{NS}}$ & $1.64 \pm 0.15^{\mathrm{NS}}$ & $0.44 \pm 0.47^{\mathrm{NS}}$ \\
December & $0.82 \pm 0.10^{\mathrm{NS}}$ & $1.73 \pm 0.08^{\mathrm{NS}}$ & $0.54 \pm 0.38^{\mathrm{NS}}$ \\
& & & \\
January & $0.73 \pm 0.05^{\mathrm{NS}}$ & $1.35 \pm 0.08^{\mathrm{NS}}$ & $0.41 \pm 0.03^{\mathrm{NS}}$ \\
\hline
\end{tabular}

\section{Discussion}

In this study, 16 genera of zooplankton from 6 Kingdom were found. Comparatively low diversity of zooplankton in this present study as compared to 35 genera from 14 phylum were reported from Trang Province, southern of Thailand and 25 genera from 11 phylum were found from Samuthsakorn province, Central of Thailand (Sirilak et al., 1998). Sampling periods may be cause of this result since this study carried only 3 months while other research spent around 1 year. However, the differences of zooplankton composition were not observed. Copepods was the most dominant group, especially calanoid and cycloipoid copepods, followed by Branchyuran larvae, crustacean nauplii and mysid larvae. Most of the genera collected from this study are known to have a wide distribution in the aquatic ecosystem (Jiwalak, 1999; Oscar et al., 2013). Copepod was reported as dominant groups from many areas (Angsupanish, 1977; Asthor and Olafur, 1995; Siokou, 1996; Tan et al., 2002; Daniel and Potter, 2004; Froneman, 2004). This zooplankton group are the most important components in the ecosystem as food source for aquatic animals (Tor et al., 2005), in addition, this organism group also economical important. This result indicated that this area suitable for ground area for aquatic larvae. Brynchyuran and larvae stages were found from this present study. Sililak (1998) suggested that founding of brynchyuran and mysid larvae indicated the important area for fisheries.

Temporal variation in zooplankton densities were not observed during study period. These results may be due to all the sampling months in the wet season. In addition, the diversity index were not significantly among sampling month as well since zooplankton densities were not differed among sampling months.

\section{Acknowledgements}

We are grateful to the department of Biology, Faculty of Science, Thaksin University, Phatthalung Campus for research facilities and fund.

\section{References}

[1] D. Guy, The ecology of the fish pond ecosystem with special reference to Africa Pergamon Press, 1992, pp 220-230.

[2] E. V. Oscar, A.A. Bassey, and E.P. Bassey, “ Ecology and diversity of zooplankton in the Great Kwa river, Cross river State, Nigeria," International Journal of Xcience and Research, vol. 2(10) pp 2319-7067. 2013.

[3] G. Asrhor and S.A, Olafur, "Seasonal cycle of zooplankton Southwest of Island," Journal of Zooplankton Research, vol. 17(10) pp1959-1976. 1995.

http://dx.doi.org/10.1093/plankt/17.10.1959

[4] J.G. Daniel, and L.C. Potter, “Composition, distribution and season abundance of ," Esturine, Coastal and Shelf Science, vol.42910 pp 117-135. 2004. 
[5] J. Jivaluk (1999). Distribution, abundance and composition of zooplankton in the South china Sea, Area I: Gulf of Thailand and East cost of Peninsular Malaysia. Pp 288-389. Available: , http://map.seafdec.org/downloads/pdf/collaborative\%20research/AreaII_West\%20Borneo/SCS_FRS2_15.pdf

[6] P. Jitchum and L. Wongrat, "Seasonal relationships between the plankton community and hydrographic conditions in a shallow oligotrophic bay, gulf of Thailand,” Kasetsart Journal (Natural Science), vol. 43 pp306-321. 2009.

[7] P. Tor, T.G., Nielson, P. Tiselius, T. Juul-Pederson, C. Michel, and E.F., Møller, "Post-spring bloom community structure of pelagic copepods in the Disko Bay, Wesern Greenland,” Journal of Plankton Research, vol.27 pp341-356. 2005.

http://dx.doi.org/10.1093/plankt/fbi010

[8] P.W. Froneman, "Zooplankton community structure and biomass in a Southern African temporarity open/closed estuary,” Estuarine, Coastal and Shel Science, vol. 60 pp 125-132. 2004.

http://dx.doi.org/10.1016/j.ecss.2003.12.002

[9] R.R. Sokla, and F.J. Rolf, Biometry. San Francisco, CA. W H Freeman. 1998.

[10] S.A. Grabe, W.W. Price, E.A.A. Abdulquder, "Shallow-water Myida (Crustacea: Mysidacea) of Bahrain (Arabian Gulf): species composition, abundance and life history characteristics of selected species,” Journal of Natural History, vol. 46, pp2315-2329. 2004.

http://dx.doi.org/10.1080/00222930310001625932

[11] S. Angsupanich, "Temporal and spatial variability of phytoplankton and chlorophyll a: lessons from the South coast of Norway and kagerrak,” ICES journal of Marine Science, vol. 55, pp1959-1976.

[12] Y. Tan, L, Huang, Q. Chen, and X. Huang, "Seasonal variation composition and grazing impact on phytoplankton standing stock in the Pear River Esutary, China," Continental Shelf and Research, vol. 24 pp

[13] Z. Ferdous, and A.K.M. Multadir, "A review: Potentiality of zooplankton as bioindicator," American Jornal of Applied Science, vol.6(10) pp 1815-1819. 2009.

http://dx.doi.org/10.3844/ajassp.2009.1815.1819 